\title{
ZESPOLENIE IDEI NARODOWEJ, ODRODZENIA RELIGIJNEGO Z PRACĄ SPOEECZNĄ DLA ROZWOJU RODZIMEJ KONCEPCJI WCZESNEJ EDUKACJI
}

[Combining the national idea of religious rebirth and basic social work in order to develop the national conception of early childhood education]

Summary: The Polish conception of early childhood education was understood to be part of a larger whole, including the relationship between the state of society, its socio-cultural and political situation, its moral and mental concepts, the educational ideal and contemporary pedagogical theory and practice. Its constituent elements were used to achieve specific goals, and they were combined into a coherent and dynamic pedagogical system. Eventually such a system was created thanks to the cooperation of such great personalities as August Cieszkowski (1814-1894), Edmund Bojanowski (1814-1871), Jan Koźmian (1814-1877) and the priest, Piotr Semenenko (1814-1886). A characteristic feature of their contribution to the development of native foundations of theory and practice of early education in the concept of rural orphanages is the fusion of the national idea and religious revival with social work.

Keywords: child, family, nation, protection, religion, early childhood education

Powstanie rodzimej koncepcji wczesnej edukacji ${ }^{1}$ jest dziełem współpracy wielkich Polaków, ludzi nauki i kultury, społeczników i twórców myśli

\footnotetext{
${ }^{1}$ Niniejszy artykuł stanowi odniesienie do badań nad dorobkiem rodzimej myśli pedagogicznej przedstawionych m.in. $\mathrm{w}$ artykule $\mathrm{Z}$ dziejów ksztattowania idei wychowania przedszkolnego na ziemiach polskich, „Acta Universitatis Nicolai Copernici. Pedagogika” 2013, nr 29, s. 67-86. Analiza źródeł wskazuje, że złożoność a jednocześnie harmonijna synteza wspierania i organizacji rozwoju i wychowania dziecka $\mathrm{w}$ wieku przedszkolnym realizowanych w ochronach wiejskich w koncepcji A. Cieszkowskiego i E. Bojanowskiego znajduje opis i wyjaśnienie w pojęciu o dużym stopniu ogólności i niejednorodności, jakim jest pojęcie edukacji. Pojmując edukację jako ogół oddziaływań służących formowaniu się, czyli zmienianiu, rozwijaniu zdolności życiowych człowieka użyto w niniejszym artykule pojęcia wczesnej edukacji. Łączy ono kształcenie i kształtowanie oraz opiekę wychowawczą nad dziećmi w wieku przedszkolnym. Zob. M. Opiela, Integralna pedagogika
} 
o wychowaniu działających na rzecz niepodległej Ojczyzny. W kontekście specyfiki potrzeb i problemów polskiego społeczeństwa oraz refleksji i praktyki pedagogicznej powstała koncepcja wczesnej edukacji w ochronach wiejskich z jej systemową organizacją praktyczną. Szczególną rolę odegrali tu: August Cieszkowski (1814-1894), Edmund Bojanowski (1814-1871), Jan Koźmian (1814-1877) i Piotr Semenenko (1814-1886). Ich współpraca oparta na zespoleniu idei narodowej, odrodzenia religijnego z pracą społeczną ${ }^{2}$ jest wyrazem odpowiedzi na potrzeby społeczne dotyczące programów dążenia do niepodległości, do obrony bytu narodowego nie przez walkę zbrojną, lecz przez rozwój oświaty i gospodarki, do budowania przyszłości narodu z troską o wierność rodzimej tradycji i ideałom wychowawczym.

Refleksja nad tym procesem ma duże znaczenie dla współczesnej teorii i praktyki wychowania, gdyż „próby i reformy wychowania, poznawane u źródła, to jest w historycznym oświetleniu osobistości ich autorów, myślicieli i pedagogów, oraz warunków ich działalności, nabierają szczególniejszego uroku: żadna $\mathrm{z}$ zasad i metod wychowawczych, rozważana teoretycznie w oderwaniu, nie wydaje się tak żywa i świeża, jak gdy ją poznajemy w chwili, gdy się rodziła i krystalizowała, na tle stosunków, w których ją ludzkość zdobyła, z ust filozofa czy działacza, który ją przejrzał, jej doniosłość ocenił i jej realizację pełnym zapału słowem głosił”’. Znajomość historii „oparta o dzieje stosunków społecznych i kulturalnych, szczególne może oddać przysługi w okresach przełomowych, kiedy naród tworząc własne szkolnictwo, szuka wskazówek i natchnienia, aby pójść drogą jak najwłaściwszą dla swoich potrzeb" ". Może stać się inspiracją dla reformatorów, dając odpowiedź na pytanie, jak organizowane było wychowanie polskiego dziecka oraz jakie i dlaczego stosowano koncepcje wychowania? Jak zachowywać się we współczesnym przełomie cywilizacyjnym, jakie wartości są sprawdzone i co wybierać? Może także ostrzec przed lekkomyślnymi krokami, zbyt teoretycznymi próbami i nowatorstwem, które nie znajdują podstaw w rzeczywistych dążeniach społeczeństwa ${ }^{5}$.

Wartość interdyscyplinarnego podejścia teoretycznego, twórczego współdziałania w dziedzinie ważnych idei i działalności społecznej pozostaje wciąż aktualna i ważna dla poznania oraz realizacji rodzimych koncepcji wychowania.

przedszkolna $w$ systemie wychowania Edmunda Bojanowskiego. Kontynuacja i zmiana, Lublin 2013, s. 273, 307-314.

${ }^{2}$ Pojęcie pracy społecznej odnosimy do XIX-wiecznej idei pracy u podstaw, która miała na celu podniesienie poziomu życia chłopów jako podstawy społeczeństwa, przede wszystkim przez szerzenie edukacji i rozbudzanie świadomości narodowej, począwszy od najmłodszego pokolenia.

${ }^{3}$ S. Kot, Historia wychowania. Zarys podręcznikowy, Lwów 1934, s. 10-11.

${ }^{4}$ Tamże, s. 13 .

${ }^{5}$ Por. tamże. 


\section{Kontekst tworzenia rodzimych form wczesnej edukacji poza rodziną}

Rozwijające się od połowy XIX wieku na ziemiach polskich ochronki wiejskie jako pozarodzinne formy wychowania małego dziecka w koncepcji A. Cieszkowskiego i E. Bojanowskiego stanowiły podstawy tworzenia systemu narodowej edukacji ${ }^{6}$. Są one prototypem współczesnych przedszkoli, a koncepcja prowadzonych w nich działań określanych mianem wychowania, opieki i nauki obejmowała istotne elementy rodzimej koncepcji wczesnej edukacji, w której wychowanie jest priorytetem.

Ochronki były tworzone dla ubogich dzieci, ale od początku zostały pomyślane jako instytucje systemu wczesnego wychowania, które z czasem miały stać się powszechne i dostępne dla wszystkich dzieci $\mathrm{w}$ wieku przedszkolnym. Błędne jest zatem określanie ich jako placówek opiekuńczych dla sierot, chociaż były one przyjmowane w pierwszej kolejności. Inspirację dla rozwoju ochronek jako rodzimych form instytucjonalnych wychowania małego dziecka stanowiła postępowa myśl pisarzy, pedagogów i projektodawców oświatowych KEN. Postulowali oni powołanie specjalnych instytucji do wychowania dziecka w wieku przedszkolnym i objęcie ich opieką przez państwo ${ }^{7}$. W świadomości wielu społeczników żywe było pragnienie stworzenia systemu edukacji i ujednolicenia całego procesu wychowawczego. Doceniano jego pierwszy etap rozpoczynający się $\mathrm{w}$ dniu narodzin dziecka i poprzez okres przedszkolny doprowadzono do wieku szkolnego. Określono go mianem edukacji pierwiastkowej.

Zawiedzione nadzieje spowodowane upadkiem powstania listopadowego oraz dotkliwe represje przyczyniły się do poszukiwania przyczyn klęski, ale także skutecznych dróg do niepodległości. Skoncentrowano się z jednej strony na wsparciu rodziny $\mathrm{w}$ wypełnianiu jej funkcji opiekuńczowychowawczej, wzmocnieniu wzajemnych więzi, uzdrowieniu obyczajów i podniesieniu świadomości narodowej poprzez kultywowanie tradycji. $\mathrm{Z}$ drugiej zaś strony koncentrowano się na trosce o dzieci jako przyszłość narodu, o wychowanie mocnych osobowości, dobrych chrześcijan i uczciwych obywateli. Wyrazem tego były zarówno charakterystyczne dla epoki refleksje filozoficzne prowadzące do powstania filozofii narodowej, twórczość literacka, włączenie się w ruch odnowy moralno-religijnej Polaków na emigracji, a także praktyczne działania społecznikowskie na ziemiach polskich pod zaborami.

Mimo niewoli i walki z polskością poddany dotkliwym represjom naród nie zatracił swej tożsamości, pomnażał dobra kultury i rozwijał dorobek w dziedzinie oświaty, myśli pedagogicznej, działalności charytatywnej

\footnotetext{
${ }^{6}$ Zob. M. Opiela, Integralna pedagogika przedszkolna..., s. 76-86.

${ }^{7}$ Zob. W. Bobrowska-Nowak, Historia wychowania przedszkolnego, Warszawa 1978, s. 74-76.
} 
i gospodarki. Wszystkich zaangażowanych w te działania łączyła silna idea patriotyczna i religijna. „Zespolenie tradycji chrześcijańskiej z kulturą narodową stworzyło ważną ostoję polskości. W trudnych dla narodu latach i w czasach przełomów Kościół był niezawodnym azylem dla «żywej polskości». Dla wielu ludzi, zwłaszcza tych, których losy rzuciły na obczyznę, oznaczała ona dostęp do polskiej kultury, zaś u ludzi religijnych - wierność wierze Ojców i kult Bogurodzicy, czym zawsze wyróżniał się polski katolicyzm" . W tym czasie Kościół był jedyną polską instytucją publiczną łączącą wszystkie zabory. Dlatego szanse przeciwdziałania systemowemu atakowi zaborców na polskość, z zamiarem rusyfikacji czy germanizacji, wiązano z Kościołem i z zakonami ${ }^{9}$.

Rozwijający się we wszystkich zaborach i na emigracji ruch odnowy przełamujący bariery zaborów, realizowany był przez wielu wybitnych mężczyzn i wiele wybitnych kobiet. Poszukiwania dróg odnowy własnej i narodowej na ziemiach polskich wiązały się z ruchem odnowy katolicyzmu $\mathrm{w}$ wielu krajach europejskich ${ }^{10}$. $\mathrm{Z}$ przekonania o znaczeniu religii i wiary w ksztaltowaniu silnych i prawych charakterów, postaw patriotycznych i budowaniu tożsamości narodowej wynikała troska o pielęgnowanie w narodzie uczuć religijnych.

Te specyficzne uwarunkowania powodowały, że edukacji rozumianej łącznie jako wychowanie i oświata dla dzieci i ludu przypisywano szczególną rolę w zachowaniu polskości, odzyskaniu niepodległości i trwaniu narodu. W sytuacji braku wolności zewnętrznej szczególną troską starano się otoczyć duchowy wymiar życia i rozwoju osoby oraz wspólnoty jaką są rodzina, naród i Kościół. Stąd realizacja wczesnego wychowania rozumianego jako jednoczenie ducha ze zmysłowością $^{11}$ była możliwa dzięki refleksji i działaniom zapewniającym harmonię wymiaru doczesnego i nadprzyrodzonego. Przeciwdziałanie systemowym działaniom antypolskim wymagało systemowych działań edukacyjnych według rodzimych tradycji wychowawczych z wykorzystaniem dorobku myśli pedagogicznej i praktycznych rozwiązań.

W Wielkopolsce w latach 40. nastąpiło ożywienie w dziedzinie edukacji i myśli pedagogicznej w publicystyce, w zakresie szkolnictwa, w dziedzinie opieki lekarskiej nad dzieckiem i wychowania fizycznego. Wzmacniało się przekonanie, że nie wystarczy nieść bezpośrednią pomoc i doraźną ulgę w cierpieniach fizycznych, trzeba przede wszystkim usunąc źródła chorób,

\footnotetext{
${ }^{8}$ A.B. Legocki, O wspótczesnym rozumieniu polskości, „Nauka” 2013, nr 4, s. 20.

${ }^{9}$ Por. J. Kłoczowski, Dzieje chrześcijaństwa polskiego, t. 2, Paryż 1991, s. 29-30.

${ }^{10}$ Por. tamże, s. 41.

11 Por. Archiwum Główne Służebniczek Dębickich w Dębicy (AGSD), Notatki Edmunda Bojanowskiego, (B); AGSD, B-h-1, k. 19r.
} 
nędzy moralnej i materialnej. Chcąc na przyszłość zapobiec niejednemu złu, trzeba stworzyć możliwie dobre warunki wychowania fizycznego i moralnego małego dziecka. Dzięki wysiłkom L. Gąsiorowskiego i E. Bojanowskiego w 1842 r. powstało Towarzystwo Poznańskie Domów Ochrony, które otworzyło pierwsze ochronki w Poznaniu (1844). Potem powstały w Wielkopolsce kolejne ochrony miejskie zakładane przez Towarzystwo Dobroczynności i przez Ligę Polską ${ }^{12}$.

Za twórców rodzimej koncepcji wczesnej edukacji należy uznać A. Cieszkowskiego, który opracował teoretyczne podstawy ochron wiejskich i E. Bojanowskiego, który zweryfikował i zrealizował je w praktyce. Dzięki współpracy $\mathrm{z}$ wieloma rzecznikami pracy organicznej i pracy u podstaw zyskała ona kształt w postaci dynamicznego systemu wychowania. Jedynie takie rozwiązanie dawało możliwość jego realizacji dzięki powołanemu przez Bojanowskiego $\mathrm{w}$ tym celu zgromadzeniu zakonnemu, zapewniającemu zaplecze personalne i materialne. $\mathrm{W}$ jego tworzeniu dużą rolę odegrali także J. Koźmian i ks. P. Semenenko. Szczególny wkład tych czterech wielkich Polaków w tworzenie rodzimych rozwiązań w dziedzinie edukacji zostanie ukazany z racji przypadającego na 2014 rok jubileuszu 200. rocznicy ich urodzin, wszyscy bowiem są rówieśnikami.

\section{Współpraca wybitnych Polaków w rozwoju rodzimej koncepcji wczesnej edukacji}

Powstające od XIX wieku na ziemiach polskich ochronki dla małych dzieci były wzorowane na doświadczeniach $\mathrm{i}$ formach sprawdzonych już na Zachodzie. W związku z tym adaptowano ich koncepcje, wybierając $\mathrm{z}$ nich niektóre elementy, a pomijając inne lub w oparciu o nie tworzono nową, odpowiadającą polskim potrzebom. Specyfika wkładu A. Cieszkowskiego, E. Bojanowskiego, J. Koźmiana i ks. P. Semenenki w rozwój rodzimej koncepcji wczesnej edukacji obrazuje całą złożoność ówczesnej sytuacji oraz potrzebę i możliwość jednoczenia różnych osób i środowisk wokół sprawy narodowej. I nie ma tu sprzeczności ani braku proporcji między życiem, poglądami i działalnością tych wielkich Polaków, między wymiarem duchowym a społecznym, dążeniem do niepodległości a wczesnym wychowaniem. Wręcz przeciwnie, to dzięki tej różnorodności, jej rozumieniu i wykorzystaniu nastąpiło zespolenie idei narodowej, odrodzenia religijnego z pracą społeczną na rzecz rozwoju rodzimej koncepcji wczesnej edukacji. Jej narodowa specyfika nie oznaczała zamknięcia na dorobek myśli ludzkiej, powszechnej

12 J. Pełkowska-Turati, Instytucje przedszkolne $w$ Wielkim Księstwie Poznańskim $w$ latach 1842-1918 ze szczególnym uwzględnieniem wychowania fizycznego, Poznań 1969, s. 55-60. 
filozoficzno-religijnej koncepcji osoby i wspólnoty, a w tej dynamice jest wierna swej tożsamości i aktualna.

Współpraca tych znamienitych osobowości koncentrowała się wokół osoby i dzieła E. Bojanowskiego. Określił on elementy systemu, w którym wychowanie jest nadrzędne wobec kształcenia i pożytku materialnego. Wprowadził w praktykę to, co teoretycznie przedstawił Cieszkowski, uzasadniając filozoficznie i historycznie potrzebę tworzenia ochron, znaczenie wczesnego wychowania dla całego życia człowieka i dobra rodziny, narodu, ludzkości. Obydwaj wskazali możliwości przygotowania wychowawczyń, model organizacji ochron i ich utrzymania. Łączenie wymiaru natury, religii i kultury wymagało rozwiązań zgodnych z doktryną Kościoła, natomiast organizacja zgromadzenia zakonnego, a w nim formacji duchowej i apostolskiej sióstr - rozwiązań prawnych, teologicznych i pedagogicznych. W tym okazali swą pomoc J. Koźmian i ks. P. Semenenko, którzy zadbali o właściwe podstawy religijno-filozoficzne dzieła i zgodność z nauczaniem Kościoła.

Współpraca w realizacji idei narodowej, tak silnie powiązanej z odnową religijną i moralną oraz rodzimą myślą filozoficzną, dokonywała się $\mathrm{w}$ pracy społecznej u podstaw. Harmonijne zespolenie idei i umiłowanie Ojczyzny w oparciu o wytrwałą pracę dla ich realizacji prowadziło do stworzenia rodzimego systemu wczesnej edukacji, który służył integralnemu wychowaniu i kształtowaniu szlachetnych charakterów. Ten dynamiczny proces można zobrazować następująco:

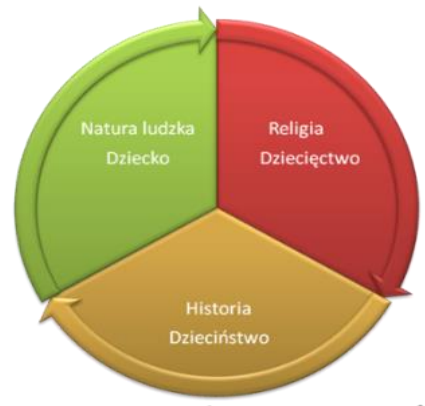

Dynamiczne zespolenie idei

Integralny rozwój i wychowania dziecka
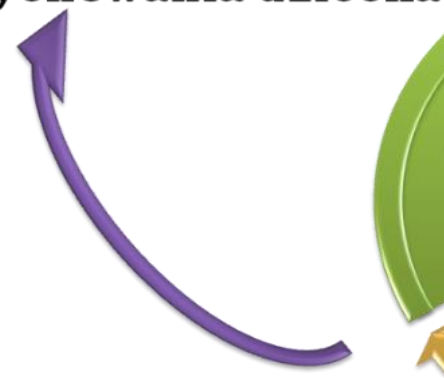

Rozwój i

wychowanie

dzieci zgodnie z natura

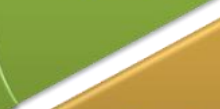

Moralne i religijne

odrodzenie narodu

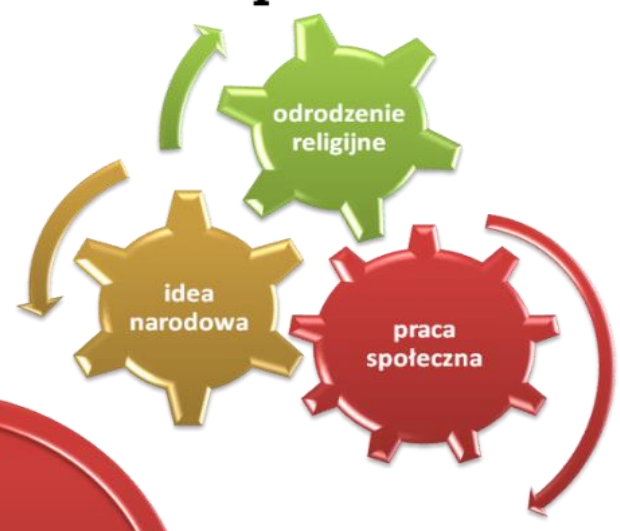

Wsparcie

rodzin

Rodzima koncepcja systemu wczesnej edukacji 
Rys. 1. Proces tworzenia koncepcji integralnego wychowania

Otwartość rodzimej koncepcji podkreślał Bojanowski twierdząc, iż „te rodzime żywioły słowiańskie, mogą się swym wpływem upładniającym pierwotnego wychowania rozlać na resztę ucywilizowanego świata"13. Podkreślał jednak, że „czym jest Narodowość dla narodu, tym wychowanie dla pojedynczego człowieka, dla każdokrotnego pokolenia" ${ }^{14}$. Jest on budowany na ogólnych podstawach filozoficzno-religijnych, gdyż „narodowość, jakkolwiek znika w najważniejszych uniwersalnych sferach, religii i filozofii w niższych atoli zostaje w swoim właściwym żywiole, a najwydatniej w dziecięcym wychowaniu"15.

Wymianę myśli i współpracę A. Cieszkowskiego i E. Bojanowskiego w sprawie ochron wiejskich zapoczątkowało spotkanie w 1842 roku w Kasynie Gostyńskim. Cieszkowski wskazał założenia teoretyczne ochron na podstawie idei i obserwacji ich urządzenia w Anglii. Jako znany już wówczas filozof, oryginalny interpretator i krytyk filozofii Hegla, myśliciel religijny, działacz społeczny i polityczny zaangażowany patriotycznie i społecznie dążył do wychowania ludu polskiego. Uwzględniał tu szeroką perspektywę myśli, czasu i ducha. Odnosząc się do analiz koncepcji dziejów w filozofii i religii uważał, że nie jest to tylko refleksja nad minionymi wydarzeniami, lecz odnosi się także do przyszłości. Na podstawie odkrytych prawidłowości w periodyzacji dziejów formułował jej wizję z przekonaniem, że prawa historii implikują bieg dziejów. Historii nadał wymiar moralny, traktując ją jako pole ścierania się dobra ze złem. Tryumf dobra jest nieustannym poszerzaniem zakresu ludzkiej wolności. Nowa filozofia czynu przejść miała od zagadnień teoretycznych do praktycznych, a jej głównym celem miała być zmiana stosunków społecznych. Miało się to dokonać nie na drodze rewolucji, lecz ewolucji przez czyn, co rozumiał jako doskonalenie tego, co zastane i takie przekształcanie rzeczywistości, by stała się doskonalsza ${ }^{16}$.

Cieszkowski pozostawał pod silnym wpływem filozofii Hegla, a jego filozofia już wówczas była przedmiotem sporów i polemik. W wyniku zatarcia w polskiej myśli filozoficznej tego okresu różnic między filozofią a religią, polityką a myślą społeczną, w jego filozofii pojawiło się błędne pojęcie na temat wiary i Kościoła katolickiego. Deklarował jednak lojalność i podkreślał jego wyjątkową rolę $\mathrm{w}$ dziejach17. Widząc zagrożoną cywilizację chrześcijańską i poszukując drogi odnowy, ochrony ludzkości przed

\footnotetext{
${ }^{13}$ AGSD, B-h-1, k. 10r.

${ }^{14}$ AGSD, B-h-1, k. 8r.

${ }^{15}$ AGSD, B-h-1, k. 19r.

${ }^{16}$ Por. Powszechna encyklopedia filozofii, Lublin 2000-2010, www.ptta.pl/pef/pdf/c/cieszkowskia.pdf, s. 2.

${ }^{17}$ Por. tamże, s. 2-3.
} 
katastrofą, ubogich przed nędzą, pragnął utorować drogę do rozwiązania kwestii społecznej ${ }^{18}$.

Wielkie nadzieje pokładał $\mathrm{w}$ wychowaniu jako ważniejszym od nauczania we wczesnym dzieciństwie. W jego mniemaniu „tylko religia jest równie potężnym czynnikiem w życiu ludów jak wychowanie". W swej refleksji zwracał się ku ludowi i dziecku, bo tak chciał „odrodzić naród od korzenia, samą krynicę życia jego oczyścić, od kolebki zaczynając hodowanie obywatela”. Ze wszystkich swych pomysłów rozwiązania kwestii społecznej ten projekt nazywał „najważniejszym i najzbawienniejszym”19. Dlatego w swej filozofii, polityce i dziełach charytatywnych powracał do sprawy wychowania dzieci z przekonaniem o jego znaczeniu dla osoby, narodu, ludzkości.

Swoją wizją i uzasadnieniem wartości, konieczności wczesnego wychowania dzieci ludu w ochronach Cieszkowski przekonał Bojanowskiego i wywarł ogromny wpływ na jego myśl pedagogiczną. Wspierał finansowo jego poczynania praktyczne mające na celu organizację ochron i kształcenia wychowawczyń. Z czasem przyjęły one formę szeroko stosowanego systemu wczesnej edukacji.

Bojanowski opierał się również na własnej wiedzy dotyczącej ochron na Zachodzie i wyciągał podobne wnioski: „instytucja ta była albo szkółką, w której małe dzieci dla przedwczesnego kształcenia rozumowego pozbawiano złotej doby ich naturalnego rozwinięcia, albo była li tylko ochroną od niebezpieczeństw i przytułkiem nędzy" ${ }^{20}$. Znajomość kultury narodowej, doświadczenie pracy oświatowej i charytatywnej z ludem oraz dla ludu była podstawą jego własnej refleksji nad procesami dziejowymi i problemami cywilizacji $\mathrm{w}$ wymiarze natury, religii $\mathrm{i}$ historii $\mathrm{w}$ wierności nauczaniu Kościoła. Znane były mu również główne idee filozofii Hegla, idealizmu oraz słowianofilstwa i mesjanizmu, z którymi zetknął się w czasie studiów we Wrocławiu i Berlinie. Na bieżąco też pozostawał $\mathrm{w}$ kontakcie $\mathrm{z}$ ich propagatorami i twórcami jako redaktor „Przyjaciela Ludu” i „Pokłosia”, aktywy członek towarzystw naukowych, kulturalnych i filantropijnych.

E. Bojanowski jako literat, działacz społeczny, twórca ochronek wiejskich, założyciel Zgromadzenia Sióstr Służebniczek NMP, kierował się rozeznaniem współczesnych potrzeb, ideą narodową, nauką Kościoła. Projekt ochron wiejskich realizował na drodze tradycji kościelnej, będąc przeciwnym staraniom Cieszkowskiego, który jako poseł na sejm w Berlinie chciał, by rząd zaborczy objął je swą opieką ${ }^{21}$. Ze względu na ich misję wychowania narodowego uznał to za niemożliwe do zaakceptowania.

\footnotetext{
${ }^{18}$ Por. L. Posadzy, Przedmowa, w: A. Cieszkowski, O ochronach wiejskich, Poznań 1849, s. V-VI.

${ }^{19}$ Por. tamże, s. IX.

${ }^{20}$ AGSD, B-h-1, k. 26r.

${ }^{21}$ E. Bojanowski, Dziennik, 15.08.1855, Wrocław 2009, t. 1, s. 706. Dalej cytowany jako Dziennik.
} 
Bojanowski podjął trud dostosowania koncepcji ochron do rzeczywistych problemów i potrzeb wiejskich rodzin polskich. Weryfikując teorię w praktyce, wyprowadzał ogólne wnioski: „Pismo Cieszkowskiego, zwrot szczególny na Ochrony wiejskie. Bo ostatni stan wiejski, ma być wszystkiem. Instytucya ta nie rozszerza się, bo nie widzi tych potrzeb nędzy, co za granicą. Musi się wprzódy nowe pojęcie tej instytucji wyrobić, bo tu też inny kierunek wziąć musi"22.

Ochrony były przeznaczone dla ubogich dzieci, ale od początku były pomyślane jako instytucje systemu wczesnego wychowania, powszechne i dostępne dla wszystkich dzieci. Zachowana w notatkach Bojanowskiego struktura planowanego dzieła pedagogicznego zawiera istotne elementy wymiaru strukturalnego, instrumentalnego i funkcjonalnego systemu wczesnej edukacji. Miał on bowiem zamiar rozpowszechnić wzór wychowania dziecka $\mathrm{w}$ pozarodzinnej formie, ale organizowanej systemowo $\mathrm{w}$ modelu rodzinnym.

Ochrony miały odpowiadać na potrzeby rozwijającej się ludzkości jako właściwa jej forma wychowania nowych pokoleń. Pisał, że „nie rozumowa pedagogika, nie układ różnorodnych części, jak państwo dotychczasowe, ale według narodowości $\mathrm{w}$ połączeniu $\mathrm{z}$ naturą rozwijać się winien system wychowania” ${ }^{23}$. Był przekonany, że „praktyka silniej przemawia nad wszelką teorią, a liczne dzieła pedagogiczne nie zwróciły tyle powszechnej uwagi na ważność i sposoby pierwotnego wychowania dzieci, ile to czynią niedawno dopiero rozwijające się Ochrony. Cel ich zakładania początkowo li dobroczynny, wywołuje coraz pożądańsze i rozleglejsze skutki na powszechne wychowanie dziecięce" ${ }^{24}$.

Podobnie Cieszkowski postrzegał problem i potrzebę przygotowania wychowawczyń ochron. Cieszkowski pisal, że „największą trudnością dla rozgałęzienia się systemu Ochron po kraju naszym będzie bezpośredni brak uzdatnionych przewodniczek czyli ochmistrzyń. Wiadomo iż pierwszy siedmioletni period życia dziecięcia, w którym fizyczna piecza przemaga, wyłącznie prawie niewieścich starań powinien być przedmiotem" ${ }^{25}$. Zaproponował więc ideę „cyrkulacji wychowania”, aby kształcić wychowanki domów sierot na wychowujące w ochronach ${ }^{26}$. Jego pragnieniem było, aby „ten zawód czyniły nie $\mathrm{w}$ chęci zysku lecz $\mathrm{w}$ duchu chrześcijańskiego poświęcenia i poczytały tenże nie za profesję, lecz za wolne śluby, za życie

\footnotetext{
${ }^{22}$ AGSD, B-f-1, k. 6 r.

${ }^{23}$ AGSD, B-h-1, k. 1 or.

${ }^{24}$ AGSD, B-h-1, k. 20v.

${ }^{25}$ A. Cieszkowski, O ochronach wiejskich, dz. cyt., s. 15.

${ }^{26}$ Tamże, s. 17-21.
} 
oddane religijno-dobroczynnemu celowi (...) - słowem jeżeli Przewodniczki staną się Siostrami Opatrzności”"27.

Myśl związania wychowawczyń w zgromadzenie zakonne podjął Bojanowski, zakładał jednak, że nie będą się wywodzić z domu sierot, ale ze zdrowych rodzin wiejskich. W 1855 r. pisał: „Od kilku lat zajmowała mnie myśl urządzenia ochronek wiejskich pod dozorem dziewcząt wiejskich. Miałem na względzie: raz - korzyść małych dzieci, wystawionych po wsiach, przez zaniedbanie lub nieświadomość rodziców na zepsucie przedwczesne, po wtóre - uświęcenie kobiet wiejskich, a przez to wpływ na podniesienie i umoralnienie ludu wiejskiego" ${ }^{28}$. Włączenie dziewcząt wiejskich w realizację tak ważnych zadań wymagało organizacji ich kształcenia i formacji, zarówno $\mathrm{w}$ wymiarze instytucjonalnym jak i religijnym, kulturowym, obyczajowym. Ta służba człowiekowi, rodzinie, narodowi, ludzkości i własnemu uświęceniu przybrała charakter religijny. Nie bez znaczenia była tu znana Bojanowskiemu sugestia: „Przez czynną religijność więcej zdziałać, niż zdziałano przez gadaninę wrzaskliwą. Poświęćmy się religijnemu wychowaniu dzieci, a spełnimy swe przeznaczenie" 29 .

$\mathrm{W}$ wysiłkach tworzenia zgromadzenia służebniczek wspierał go ideowo i praktycznie Jan Koźmian, świecki „brat zewnętrzny” zmartwychwstańców, potem ksiądz, prawnik, ultramontanin, publicysta i działacz społeczny, redaktor naczelny „Przeglądu Poznańskiego”. Miał on także wpływ na Bojanowskiego w kształtowaniu jednoznaczności postawy i dzieła, intencji i jasnej deklaracji religijno-filozoficznej. Niewątpliwie jego troska o czystość doktryny kościelnej i związanej z nią myśli filozoficznej przyczyniła się do uniknięcia wpływu idealizmu i błędnych idei religijnych Cieszkowskiego oraz zachowania koncepcji wychowania w realizmie.

Koźmian włączył się w realizację koncepcji odrodzenia katolickiego wypracowanej przez B. Jańskiego, która bazowała na ultramontanizmie. Rozważając silne zespolenie polskiego patriotyzmu i wiary, Jański określił zarysy jego polskiej odmiany, w której laikat miał odgrywać czołową rolę. Zwracał uwagę, że poprzez sam katolicyzm i odrodzenie moralne, bez radykalnych środków rewolucyjnych, Polska może być zbawiona. Kładł również nacisk na wewnętrzny związek sprawy polskiej ze sprawą Kościoła, a nauka papieska miała stanowić dla Polaków wytyczne w prowadzeniu

${ }^{27}$ Tamże, s. 30-31.

28 E. Bojanowski do abpa L. Przyłuskiego, 8.12.1855, w: Korespondencja Edmunda Bojanowskiego z lat 1853-1871, oprac. L. Smołka, Wrocław 2001, t. 1, s. 168.

29 „Przyjaciel Ludu” 23.01.1847, nr 4, R. XIV, s. 31. 
działalności politycznej ${ }^{30}$. Celem zmartwychwstańców i ich świeckich braci było utrzymanie i umacnianie wiary ojców jako jedynej zasady patriotyzmu i wolności, jedynej rękojmi przyszłej niepodległości ${ }^{31}$.

Cele te zmartwychwstańcy realizowali poprzez wprowadzanie zasad chrześcijańskich w życie publiczne i prywatne na ziemiach polskich i na emigracji, ogłaszanie drukiem pism, książek, prowadzenie badań naukowych dotyczących dziejów narodów słowiańskich i ich wiary. Zakładali także katolickie biblioteki i czytelnie, obejmując swą działalnością wszystkie dziedziny życia społecznego ${ }^{32}$. Zasadniczym elementem ich duchowości było przekonanie, że do wiary w zmartwychwstanie należy praktyka zmartwychwstawania $\mathrm{w}$ życiu codziennym ${ }^{33}$. Ten program odnowy realizowali według określonej przez Jańskiego wizji wychowania społeczeństw. Chodziło w nim o „stworzenie nowego społeczeństwa opartego na odnowionym człowieku. Wychodząc od wychowania religijnego, przechodził ku dziedzinie wychowania społecznego, w tym głównie obywatelskiego, patriotycznego i politycznego"34.

Uformowany $\mathrm{w}$ tym duchu Koźmian włączał Bojanowskiego $\mathrm{w}$ realizację tych celów, pomagając mu w działaniach oświatowych, publicystycznych i literackich, wspierając go finansowo. Jego mocne przekonania $\mathrm{w}$ zakresie doktryny i poświęcenie sprawie narodowej ukierunkowały Bojanowskiego w poszukiwaniu ostatecznego kształtu systemu wychowania $\mathrm{w}$ ochronach i formacji służebniczek. Pomagał mu w pisaniu Reguty tworzonego ich zgromadzenia. W sprawie najważniejszych rozwiązań dotyczących formacji duchowej, spełnienia misji i zatwierdzenia Reguty skontaktował Bojanowskiego z ks. P. Semenenką. Ten gorliwy zmartwychwstaniec, filozof-tomista, teolog katolicki, pomagał $\mathrm{w}$ zakładaniu wielu żeńskich zgromadzeń zakonnych.

Poglądy filozoficzne Semenenki kształtowały się pod wpływem filozofii nowożytnej i kierunków filozoficznych XIX wieku oraz prądów tradycjonalistycznych. Studiując pod kierunkiem jezuitów, podjął polemikę z ówczesnymi kierunkami filozoficznymi, a pod wpływem ich nauki wyzwolił się spod wpływu Kanta i niemieckich idealistów. Studiowanie dzieł św. Augustyna i św. Tomasza z Akwinu przyczyniło się do przełomu w jego

\footnotetext{
${ }^{30}$ Por. J. Kurzycki, Koncepcja działalności laikatu wg Bogdana Jańskiego w kontekście zadań świeckich $w$ Kościele katolickim, w: Dziedzictwo Bogdana Jańskiego. Stużba Narodowa, red. S. Urbański, Warszawa 2007, s. 109-133, 119.

${ }^{31}$ Por. tamże, s. 114.

${ }^{32}$ Por. tamże, s. 117 .

33 Zob. J. Kostkiewicz, Zgromadzenie Zmartwychwstania Pańskiego i jego system wychowawczy, w: tejże (red.), Pedagogie katolickich zgromadzeń zakonnych, Kraków 2012, t. 1, s. $310-317$.

${ }^{34}$ Tamże, s. 318-319.
} 
myśleniu. W odrodzonym tomizmie dostrzegł kres swoich poszukiwań filozoficznych. Podjął próbę tworzenia własnego systemu filozofii, a jego myśl koncentrowała się wokół intencji uczynienia filozofii nowożytnej filozofią chrześcijańską ${ }^{35}$. On też ukierunkował myśl teologiczno-filozoficzną Bojanowskiego na płaszczyznę realizmu filozoficznego i nauki Kościoła zarówno w dziedzinie doktryny, jak i praktyk religijnych właściwych dla katolickiej formacji, świadectwa życia i służby w duchu przykazania miłości.

Swym autorytetem w sprawach religijnej formacji służebniczek wspierał Bojanowskiego, który pisał: „opierając się co do tego na poważnym zdaniu o. Semeneńki, widzę się zniewolonym obstawać za ich cotygodniową spowiedzią" ${ }^{36}$. W czasie odwiedzin w 1858 roku w nowicjacie służebniczek w Jaszkowie udzielił Bojanowskiemu wielu cennych rad, zapewnił artykuły do „Pokłosia” i wsparcie w staraniach o zatwierdzenie zgromadzenia przez Stolicę Apostolską ${ }^{37}$.

Koźmian i Semenenko wnieśli niezwykle ważny wkład w ostateczne uksztaltowanie podstaw teoretycznych integralnego wychowania osoby. Zapewnili określenie odpowiednich warunków dla realizacji wychowania dzieci, edukacji ludu, formacji zakonnej dla służby Bogu, ludziom i Ojczyźnie opartej na zdrowej doktrynie katolickiej. Ta z kolei odpowiadała chrześcijańskiej myśli filozoficznej, szczególnie antropologii i idei narodowej.

\section{Wymiary integralnego wychowania w ochronach}

Instytucja ochron miała być pierwszym szczeblem opieki społeczeństwa nad swymi członkami. Według Cieszkowskiego „dobroczynny swój wpływ nad człowiekiem od kolebki do grobu rozciągać powinna; ale której działanie na wiek dziecinny najznaczniejsze być musi, ponieważ w tym periodzie bezsilna jednostka mająca się na członka społeczności wykształcić, najwięcej jej pomocy wymaga" ${ }^{\text {" }}$. Znajomość dziecka i respektowanie praw jego rozwoju $\mathrm{z}$ jednej strony, a z drugiej wprowadzanie w świat wartości chrześcijańskich, których realizacja w tradycji, zwyczajach i życiu codziennym miała prowadzić do szlachetnego życia oddanego Bogu i Ojczyźnie, było zaszczytnym i odpowiedzialnym zadaniem ochroniarek. Uzasadnienie dla takiego postrzegania i budowania rzeczywistości Bojanowski formułował na podstawie właściwej sobie analizy zmierzającej do zrozumienia istoty godności

\footnotetext{
${ }^{35}$ Por. T. Kaszuba, Niektóre charakterystyczne elementy filozofii ks. Piotra Semenenki CR, „Zeszyty Historyczno-Teologiczne” 2004, nr 10, s. 21-33.

${ }^{36}$ Dziennik, 20.04.1858, t. 2, s. 400.

${ }^{37}$ Zob. tamże, 19.11.1858, t. II, s. 501; 20.11.1858, t. II, s. 502.

${ }^{38}$ A. Cieszkowski, O ochronach wiejskich, dz. cyt., s. 2.
} 
i roli kobiety oraz wychowania na przestrzeni dziejów w aspekcie natury, religii i historii ${ }^{39}$.

W centrum koncepcji wczesnej edukacji była osoba - dziecko i wychowawczyni $\mathrm{w}$ relacji wzajemnej wymiany wartości na drodze ich całożyciowego procesu osobowego doskonalenia. Koncepcja ta była ujmowana w modelu zintegrowanym, obejmując etap wychowania dziecka od urodzenia do podjęcia nauki w szkole, dokonujący się w rodzinie i ochronie. Integralne wychowanie dziecka do siódmego roku życia wymagało świadomości tego, kim ono jest w wymiarze natury, religii i historii. Dlatego Bojanowski poznając, jak „lud wyczuwa potrzebę od najpierwszych chwil życia pielęgnować troskliwie, tak wewnętrzną, jakoli zewnętrzną stronę dziecięcia"40, określił kim jest „dziecko według pojęć ludu” ${ }^{4}$. Służebniczki zobowiązał w Regule, aby dzieci jako najdroższy skarb Chrystusa Pana, starannie i z miłością pielęgnowały ${ }^{42}$ $\mathrm{z}$ odniesieniem do specyfiki ludu. W części II Reguły $w$ szczególności zawarł polecenie, że „dzieci w ochronce mają być już zaprawiane z małości do spraw całego życia ludzkiego"43, wskazując program, zadania sióstr i metody pracy. Wymagał od nich znajomości oraz kultywowania tradycji wychowawczych i zwyczajów ludu. Prawidłowości rozwoju dziecka, jego potrzeby i możliwości siostry miały poznawać przez obserwację, szczególnie podczas zabaw, aby je umiejętnie rozwijać. We wspomaganiu harmonijnego rozwoju dziecka obejmującego wszystkie sfery jego osobowości najważniejszą metodą był wpływ osobistego przykładu w relacji wzajemności, co można zobrazować następująco:

${ }^{39}$ AGSD, B-i-1, k. 11 .

${ }^{40}$ AGSD, B-h-5, k. 36r.

${ }^{41}$ Zob. AGSD, B-h-5, k. 32r-36v.

${ }^{42}$ Reguła Zgromadzenia Stużebniczek Boga Rodzicy Dziewicy Niepokalanie Poczętej, cz. I, Poznań 1867, §44.

${ }^{43}$ Regula, cz. II, §15. 


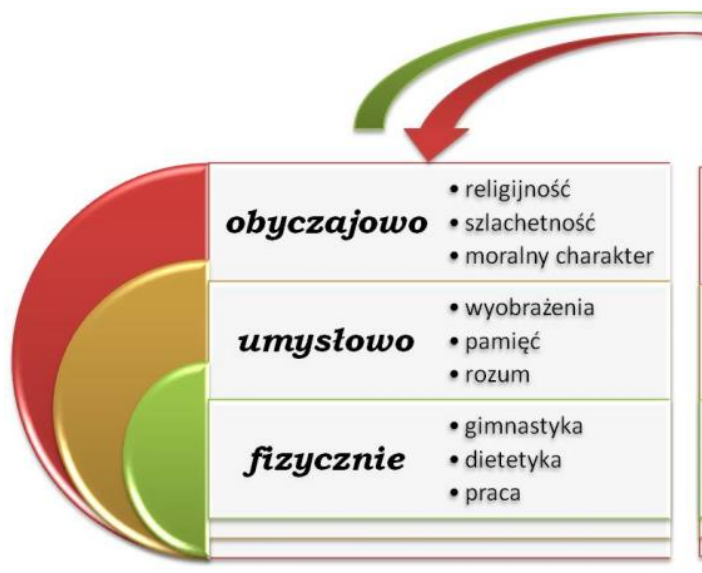

Dziecko

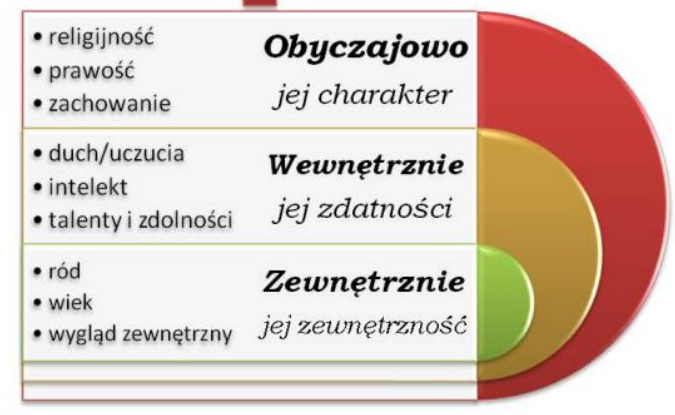

Wychowawczyni

Rys. 2. Wzajemność wpływu podmiotów wychowania.

Ochroniarki zaangażowane w wychowanie dzieci zobowiązał również, aby swoim życiem uświadamiały matkom, dziewczętom, kobietom ich rolę oraz godność. Nie tylko Bojanowski, ale i jemu współcześni myśliciele, a także społecznicy upatrywali w zaangażowaniu w wychowanie na rzecz niepodległej Ojczyzny kobiet-matek, świadomych obywatelek skuteczną drogę odrodzenia narodu. Realizacja tego zamiaru wymagała jasnych podstaw filozoficznych, religijnych i społeczno-kulturowych, na których budowano stałe, systemowe rozwiązania odpowiadające naturze i kulturze osób, rodzin, ludu oraz narodu.

Bojanowski, by jak najlepiej odpowiedzieć na potrzeby ludności wsi polskiej, przedstawił zasadę: „Co do wyboru ochroniarek dla Ochronek wiejskich, przede wszystkim zasługuje na wzgląd, aby były wieśniaczkami" ${ }^{4}$. Od tej zasady nie odstępował, uzasadniając ją troską o ich osobisty wpływ na dzieci. Pisal, że „słowa nauki tu nie wystarczą: dzieci, lud, nie słowem, lecz życiem uczyć trzeba, jak żyć mają”. Był zresztą przekonany, że „ochmistrzynie ze stanu miejskiego byłyby ze wszech miar zaczynem obcego w ludność wiejską żywiołu, tym szkodliwszym, że właśnie najgłębiej, bo w pierwotne wychowanie wmieszanym" 45 .

Ukazał również szczegółowo obowiązki i zasadność wyboru dziewcząt wiejskich, które „równością stanu swego z ludnością wiejską dają rękojmię łatwiejszego przyjęcia się tej nowej instytucji we wioskach naszych (...). Nie wytępiając starodawnych zwyczajów i obyczajów rodzinnych, mogą takowych prostotę, swojskość i poczciwość odnowić i od grożącej im zagłady stanowczo ocalić. Jak bowiem wewnętrzne życie naszego ludu, jego religijność, jego

\footnotetext{
${ }^{44}$ AGSD, B-f- 1 , k.1 4V.

${ }^{45}$ Por. AGSD, B-f- 1, k. $15 \mathrm{v}$
} 
poezja ustna i obrzędowa, jego zwyczaje i cała tradycja rodzima jest wyłącznym prawie dziedzictwem niewiast, tak też obyczaje, cnoty i wady ludu, są niewiast zasługą, lub winą"46.

W ochronkach Bojanowski widział szansę na odrodzenie moralne i był przekonany o ich wartości w wymiarze społecznym i religijnym. Pisał: „Tu więc zacząc się musi odrodzenie ludzkości. Przede wszystkim w życiu rodzinnym, domowym, w obrębie pierwotnego wychowania" ${ }^{\text {"7 }}$. Podkreślał, że „życie rodzinne jest główną dziedziną narodu", a kobieta pełni w niej niezastąpioną rolę jako matka, wychowawczyni. „Ona jest zachowawczynią tradycji, jest wcieloną Ojczyzną, fizycznie i duchowo. Jest karmicielką niemowląt, żywicielką rodziny, ona przyodziewa, opatruje fizycznie i duchowo potrzeby, jest wychowawczynią"48.

Wysokie wyobrażenie o przeznaczeniu rodziny miał także Cieszkowski, który uważał, że zburzenie „tej wielebnej twierdzy Ducha” wywołałoby „społeczne powodzie i kataklizmy”. W jego zamiarze ochrona miała pomagać rodzinie i wynagradzać dzieciom „opieszałość lub nieudolność matek”. Zalecał w tym ostrożność jak największą, aby ochrona nie osłabiała rodzinnych uczuć dziecka, nie prowadziła do zobojętnienia wzajemnego stosunku i uczuć przez zwolnienie rodziców od troski o dzieci, co byłoby „szkodą niepowetowaną" ${ }^{4}$.

Bojanowski zainspirowany przez Cieszkowskiego wprowadzał w praktykę idee wychowawcze. Zalecali stosowanie odpowiednich środków wychowawczych do „prowadzenia i do naturalnego kształcenia dzieci, prawie bez żadnej nauki, prawie bez żadnych sztucznych środków, lecz że tak powiem samą potęgą opieki społeczeństwa, samym przykładem emulacji, porządkiem, zabawą, naturalnymi ćwiczeniami, usunięciem szkodliwych wpływów i nałogów oraz obudzeniem w nich ludzkiej duszy, całą swą siłę czerpiąc u źródła religii i dobrej woli. Temu obyczajowy wpływ Ochron na całe życie jej wychowanków oraz wyższa ważność tego wpływu nad nieurodzajną naukę po szkółkach udzielaną, muszą być jawne" ${ }^{50}$. Zgodni byli zatem co do priorytetu zadań wychowawczych i sposobów ich realizacji w ochronkach.

${ }^{46}$ AGSD, B-f- $1, k \cdot 15 \mathrm{v}-16 \mathrm{r}$.

${ }^{47}$ Por. AGSD, B-f-1, k. 2v-6r.

${ }^{48}$ AGSD, B-i-1, k. 11r.

${ }^{49}$ Por. L. Posadzy, Przedmowa, s. X.

${ }^{50}$ Zob. A. Cieszkowski, O ochronach wiejskich, s. 12; por. AGSD, B-h-1, k. 22r-v. 


\section{Idea ochrony we wczesnej edukacji i społeczne znaczenie ochron wiejskich}

W pierwszej połowie XIX wieku na terenie Wielkopolski nie było żadnej ochronki wiejskiej ${ }^{51}$. Mimo ich wielkiej potrzeby nieznajomość tego sposobu pracy z dziećmi natrafiała na trudności, jakimi były brak wykwalifikowanych sił, przykładu i wzoru organizacyjnego ${ }^{52}$. Zawartą w rozprawie Cieszkowskiego O ochronach wiejskich myśl z zainteresowaniem i zrozumieniem ważności wczesnego wychowania dzieci wiejskich i pragnieniem działania $\mathrm{w}$ tym kierunku podjął E. Bojanowski. Dlatego też, jak już wskazano wyżej, można ich uznać za twórców rodzimej koncepcji wczesnej edukacji.

Towarzyszyło im głębokie przekonanie o potrzebie i wartości organizowania ochron. Znane im były metody pedagogiczne praktykowane w zakładach dla małych dzieci i ówczesne koncepcje wczesnego wychowania, ale poszukiwali modelu optymalnego wychowawczo. Bojanowski podjął krytyczną ocenę dotychczasowego dorobku, jak pisal: „Co do samego zaś systemu wychowania, takowy w Ochronach dotychczasowych, nosi jeszcze piętno szkolnictwa (...) już sama natura dziecięcego wieku wskazała potrzebę wprowadzenia do niej fizycznego żywiołu, a mianowicie gimnastyki i naocznego nauczania, wszelako wybór samychże przedmiotów i naukowa ścisłość ich traktowania nosiły szkolnicze piętno swej epoki i wszędzie zbyt naukowe żywioły uzurpacyjnie parły na Ochronę. Dowodem tego wprowadzenie do Ochron nauki czytania, pisania, zbytnia specjalność historii naturalnej, itp. (Diesterweg Wertheimer) tudzież pedantyczny podział godzin, zwyczajne, mianowicie w Niemczech, przydawanie Ochronom Nauczycieli obok Ochmistrzyń. Z obojga stron, tak fizycznej jak i moralnej, okazały Ochrony wnet swą nieocenioną dla społeczności pożyteczność; zawsze jednak pierwszy wzgląd praktyczny, materialny wyraźnie trzymał jeszcze przewagę nad duchowym i obyczajowym" ${ }^{33}$.

Obydwaj zmierzali do nadania ochronie charakteru instytucji wychowania małych dzieci z uwzględnieniem ich natury i indywidualności. Ta nowa instytucja miała być miejscem odrodzenia pojedynczych pokoleń, które miały nieść odrodzenie ludzkości w wymiarze duchowym i obyczajowym ${ }^{54}$. Nie korzystali jednak bezkrytycznie z obcych wzorów. Bojanowski świadomie dążył do tej specyfiki narodowej pisząc za Mickiewiczem: „Niejedna myśl, co w oświeconej Europie nie rozwinęła się jeszcze do najdalszych następstw, w Słowiańszczyźnie wypełniona już stawi przed oczy skutek rzeczywiście

\footnotetext{
${ }^{51}$ A. Cieszkowski, O ochronach wiejskich, s. 10.

${ }^{52} \mathrm{~J}$. Pełkowska-Turati, Instytucje przedszkolne..., s. 53.

${ }^{53}$ AGSD, B-h-1, k. 2or.

${ }^{54}$ Por. AGSD, B-f- 1, k. 8 r.
} 
otrzymany. Gdyby teorie zachodu tak chwytane przez Słowian, i praktyczne życie słowiańskie tak nie znane Zachodowi złączyła pilna uwaga, może by przez to oszczędziło się dla ludzkości wiele daremnych, a przykrych doświadczeń reformatorskich" 55 .

Bojanowski, mimo wpływu koncepcji ochron wiejskich i myśl filozoficznej Cieszkowskiego, sam poszukiwał sposobu ich organizacji najbardziej odpowiedniej polskim warunkom. Zanim zaczął wprowadzać ją $\mathrm{w}$ życie, wpierw szukał zrozumienia istoty samego pojęcia: „Ochrona = ochranianie, szanowanie, oszczędzanie, całość, nienaruszalność - schronienie - zachowanie. Ochraniać = nienaruszać, nienaruszenie zachować, od szkody uwarować - szanując, zachować" ${ }^{56}$. Tworząc ochrony dla ludu i dzieci wiejskich, określił ich charakter i misję, w której znalazło wyraz zespolenie idei narodowej, idei odrodzenia religijnego z pracą społeczną wśród ludu, przez lud i dla ludu. Stąd wyprowadzał główną ideę, iż: „Na podobieństwo tej widzialnej ochrony, a pospólnej strzechy macierzyńskiej - jest wszystek nasz lud żywą Ochroną świętych obyczajów rodzinnych. (...) W tym rozumieniu duchowna nasza Ochrona ma być wewnętrznym ogniskiem domowym, które ma oświecać tak te święte progi i ściany rodzinne, jak i tulącą się w nich czeladkę Bożą ogrzewać. Ochrona (...) bierze swoją nazwę od chronienia, zachowywania i szanowania świętych obyczajów rodzinnych" ${ }^{57}$.

\section{Zakończenie}

Faktem jest, że A. Cieszkowski, który opracował koncepcję teoretycznie oraz Bojanowski, który jako pierwszy z powodzeniem zakładał ochrony na wsi, zostali docenieni już przez współczesnych: „Dalecy jesteśmy od ujmowania zasługi A. Cieszkowskiemu, że on pierwszy u nas w kraju myśl o ochronkach poruszyl, ale pozwolimy zrobić sobie uwagę, że wyłuszczył on tylko zasadę rzeczy pod względem ogromnego znaczenia społecznego tejże instytucji. Tymczasem nie zaprzeczając ważności tego ogólnego znaczenia, instytucja Ochronek wiejskich musi mieć dwie inne podstawy, by się w naszym kraju mogła przyjąć i przynieść owoce, to jest musi być opartą na religii i odpowiednia naszym wiejskim zasobom, jednym słowem najtańszą. Aby tym potrzebom kraju naszego $\mathrm{w}$ rzeczonych warunkach odpowiedzieć, należy zwrócić uwagę na ochrony zakładane przez E. Bojanowskiego" ${ }^{\text {. }}$.

Refleksja nad tym ważnym dziełem społecznym, podejmowana zarówno przez Cieszkowskiego jak i Bojanowskiego, nie była jedynie

\footnotetext{
${ }^{55}$ AGSD, B-f-1, k. $6 r$.

${ }^{56}$ AGSD, B-k-4, k. $29 r$.

${ }^{57}$ AGSD, B-k-4, k. 31v.

58 „Czas” 1954, nr 42.
} 
romantyczną fantazją ani doraźnym aktem społecznikowskiej aktywności. Towarzyszyła jej pogłębiona analiza $\mathrm{w}$ wymiarze filozofii, religii, historii, kultury i tradycji narodowej, dorobku myśli i praktyki pedagogicznej w kraju, a także za granicą oraz wnikliwa obserwacja życia. Ukierunkowana przez Koźmiana i ks. Semenenkę, zyskała stały i jednoznaczny fundament filozoficzno-religijny dla dynamicznego systemu wczesnej edukacji, uwzględniającego wszystkie wymiary jego narodowej specyfiki, aktualnego do dziś.

Streszczenie: Polska koncepcja wczesnej edukacji została wpisana w uzasadnioną całość obejmującą związek między stanem społeczeństwa, jego sytuacją społeczno-kulturową, polityczną, jego pojęciami moralnymi i umysłowymi a ideałem wychowawczym, ówczesną praktyką i teorią pedagogiczną. Tworzące ją elementy służą realizacji określonego celu i zostały ujęte w spójny, dynamiczny system pedagogiczny. Ostatecznie ukształtował się on dzięki współpracy takich wielkich osobowości jak: Edmund Bojanowski (1814-1871), August Cieszkowski (1814-1894), Jan Koźmian (1814-1877) i Piotr Semenenko (1814-1886). Cechą charakterystyczną ich wkładu w rozwój podstaw rodzimej teorii i praktyki wczesnego wychowania $\mathrm{w}$ koncepcji ochron wiejskich jest zespolenie idei narodowej i odrodzenia religijnego z pracą społeczną.

Słowa kluczowe: dziecko, rodzina, naród, ochrona, wczesna edukacja 